\title{
山間部で生産された煎茶の香りに関する一考察
}

\author{
国立研究開発法人 \\ 農業・食品産業技術総合研究機構 \\ 果樹茶業研究部門* \\ 水上裕造 ${ }^{\dagger}$
}

(2018年 7 月 5 日受理)

\section{Characteristic Aroma of Sencha Produced in the Mountainous Area}

\author{
Yuzo Mizukami \\ Institute of Fruit Tree and Tea Science, NARO
}

\begin{abstract}
Summary
The odorants contributing to the characteristic aroma of sencha produced in the mountainous area have been investigated by using an aroma extract dilution analysis (AEDA) of the volatile fractions isolated from the sencha infusion by comparing that produced at the flat land. Principal component analysis of the flavor dilution factors of all the detected odorants in the AEDA has revealed that furaneol, (Z)-methyl jasmonate, indole and vanillin were the characteristic odorants of the sencha produced in the mountainous area. Since these odorants were also included in the infusion of sencha produced at the flat land, the characteristic aroma of sencha produced in the mountainous area would be affected by the odorants compositions. The experimental result in this study have been obtained by using limited samples. It would be necessary to analyze more samples, to clarify the aroma of sencha produced in the mountainous area.
\end{abstract}

Key words : mountainous area, sencha, odorant, aroma extract dilution analysis.

キーワード：山間部, 煎茶, 香気寄与成分, 香気エキス希釈分析

\section{1 緒 言}

古来，良質な茶の生産は気候がやや泠涼で昼夜の温度 の差が大きく，霧深い川沿いの山間部が適することが知 られている ${ }^{1)}$ 。山間部で生産された煎茶は平坦部で生産
された煎茶に比べ, 外観, 香気および滋味に優れ, 特に 香気に差があるとこが認められている2゙。その要因とし て, 気温の日較差, 降水量など気象による影響が大きい ことが考察されている ${ }^{2)}$ 。しかし，山間部で生産された 煎茶の香りについて解明を試みた報告は見当たらない。 茶の香りの分析に, 人の鼻を検出器に利用したガス 
クロマトグラフィーーオルファクトメトリー (GC-O) が用いられるようになり, 煎茶 ${ }^{3,4)}$, ほうじ茶 ${ }^{3)}$, 半発 酵茶 $^{5)}$, 紅茶 ${ }^{4)}$ の香りの解明が進められた。GC-Oを 用いれば，閾值が低くGCでは検出されにくい重要な香 気寄与成分も検出できるようになる。さらに, GC-O を用いた香気エキス希釈分析 (Aroma Extract dilution Analysis, AEDA）により, 各香気寄与成分の元の香り への影響度合いが明らかになる。加えて, 香気エキスの 抽出にSolvent-assisted flavor evaporation (SAFE) 装 置による高真空蒸留が用いられるようになり ${ }^{6)}$ ，水溶性 および高沸点成分を効率よく回収でき，元の香りをよく 再現する香気エキスで香りが解析できるようになった。 このような解析方法の進展により，茶の香りが解明され つつある ${ }^{3,4)}$

今回, 山間部として静岡県榛原郡川根本町で生産され た煎茶と平坦部で生産された煎茶を材料として, SAFE 装置により香気エキスを得て，GC-OによるAEDAでそ れらの香りを解析した。さらに, AEDAで得られた結 果を主成分分析したところ，山間部の煎茶の香りの特徵 が明らかになったので報告する。

\section{2 実験方法}

\section{1 材料}

材料に用いた山間部の煎茶は2015年，2016年および 2017年に静岡県榛原郡川根本町に所在する松島園および つちや農園で摘採 (露地栽培) および製造された品種 ‘や ぶきた’の煎茶 (荒茶) を用いた。なお，平坦部の煎茶 は農研機構果樹茶業研究部門金谷茶業研究拠点試験研究 固場で摘採(露地栽培)および製造された品種“やぶきた” の煎茶（荒茶）である。煎茶は火入れにより香りが大き く変化する ${ }^{3,4)}$ 。火入された煎茶よりも荒茶を用いた方 が山間部の香りの特徵がわかりやすいため, 解析には荒
茶を用いた。摘採日および原葉形質のデータをTable 1 に示す。いずれも蒸度は普通蒸しであり, 製造後窒素置 換し分析まで温度 $-40^{\circ} \mathrm{C}$ 下で保存した。

実験で利用する有機溶媒は蒸留してから用いた。Table 2 に示した成分No. 1，2，5，7，10-12，17，18，12-18， 20-22, 24-28, 32-35, 38, 40-43, 45, 46, 48, 49, 51, 52，54-57，61，63，64，66は東京化成工業(東京)から， No.23，29，37，39，53はシグマアルドリッチジャパン(東 京）から, No.65は和光純薬工業（大阪）から入手した。 成分No.14 ${ }^{7)} ， 15^{8)} ， 16^{9)} ， 36^{10)} ， 47^{11)}$ は既報の方法で合 成した。No. 3 1-penten-3-oneは1-penten-3-ol（東京 化成工業)を, No. $8(Z)$-3-hexenalは $(Z)$-3-hexenol(東 京化成工業)を, No.13 1-octen-3-oneは1-octen-3-ol(東 京化成工業）を基質として, Mukaiyamaya ${ }^{12)}$ の方法 を参考に $N$-tert-butylphenylsulfenamide（東京化成工業） を触媒， $N$-Chlorosuccinimide（東京化成工業）を共酸 化剂として合成した。

各成分の保持指標を求めるため, paraffin $\left(\mathrm{C}_{6}-\mathrm{C}_{27}\right)$ は東京化成工業から入手した。

\section{2 香気エキス抽出方法}

既報 ${ }^{5)}$ に従い，浸出液100 Lから香気エキス0.1 mLを 得た。

\section{3 香気寄与成分の機器分析}

$\mathrm{GC}-\mathrm{O} /$ 水素炎イオン化検出器 (FID) 分析およびGCマススペクトロメトリー (MS) 分析は既報 ${ }^{6,13)}$ に従った。

\section{4 AEDA}

既報 ${ }^{13)}$ と同様に，香気エキス0.1 mLをdichloromethane で10倍，100倍，1000倍，10000倍に希釈し，GC-O分析 した。なお, 分析は 3 回繰返し, その内 2 回以上匂いが 検出される最大の希釈倍率をFDファクターとした。

Table 1. Characteristic of Raw Material Leaves and Sensory Test's Scores for the Sencha Produced in the Mountainous (Mt.) Area and Flat Land

\begin{tabular}{|c|c|c|c|c|c|c|c|c|c|c|c|c|c|c|c|c|}
\hline \multirow[b]{3}{*}{ Year } & \multirow{2}{*}{\multicolumn{2}{|c|}{ Plucking }} & \multicolumn{5}{|c|}{ Characteristic of Raw Material Leaves } & \multicolumn{9}{|c|}{ Characteristic of Sencha } \\
\hline & & & \multirow{2}{*}{$\begin{array}{l}\text { Weight of } \\
100 \text { Shoots } \\
\mathrm{g}\end{array}$} & \multirow{2}{*}{$\begin{array}{c}\text { Length of } \\
\text { New Shoot } \\
\text { mm }\end{array}$} & \multirow{2}{*}{$\begin{array}{c}\text { Rate of } \\
\text { Leaves } \\
\%\end{array}$} & \multirow{2}{*}{$\begin{array}{l}\text { Bulk } \\
\text { Density } \\
\mathrm{kg} \cdot \mathrm{m}^{-3}\end{array}$} & \multirow{2}{*}{$\begin{array}{c}\text { Rate of } \\
\text { Banjhi Shoot } \\
\%\end{array}$} & \multicolumn{5}{|c|}{$\begin{array}{l}\text { Sensory Evaluation } \\
\text { Quality of Liquor }\end{array}$} & \multirow{2}{*}{ total } & \multirow{2}{*}{\multicolumn{3}{|c|}{$\begin{array}{l}\text { Evaluation by Using } \\
\text { Character Whee }\left.\right|^{\mathrm{b}}\end{array}$}} \\
\hline & Date & Production & & & & & & Shape & Color & Aroma & Color & Taste & & & & \\
\hline 2015 & $27-\mathrm{Apr}$ & & 55 & 94 & 74 & 112 & 8 & 15 & 15 & 14 & 14 & 14 & 72 & green & sweet spicy & burnt \\
\hline 2016 & 26-Apr & $\begin{array}{c}\text { Kanaya } \\
(f \mid a t\end{array}$ & 48 & 96 & 72 & 102 & 3 & 15 & 15 & 14 & 14 & 14 & 72 & green & sweet spicy & dry \\
\hline 2017 & 7-May & & 59 & 104 & 73 & 99 & 17 & 15 & 14 & 14 & 14 & 14 & 71 & green & sweet spicy & vegetable \\
\hline 2015 & 30-Apr & & 50 & 86 & 73 & 124 & 3 & 15 & 15 & 14 & 14 & 14 & 72 & green & sweet dry & vegetable \\
\hline 2016 & 1-May & Matsushimaen & 45 & 84 & 75 & 121 & 0 & 15 & 15 & 15 & 15 & 15 & 75 & green & sweet flowery & spicy \\
\hline 2017 & 12-May & & 54 & 95 & 75 & 109 & 2 & 14 & 15 & 15 & 14 & 14 & 72 & green & sweet dry & vegetable \\
\hline 2015 & 8-May & & 65 & 111 & 69 & 126 & 3 & 15 & 14 & 14 & 15 & 15 & 73 & green & sweet flowery & vegetable \\
\hline 2016 & 2-May & Tsuch iyanouen & 47 & 85 & 73 & 128 & 0 & 15 & 14 & 15 & 15 & 15 & 74 & green & sweet flowery & fruity \\
\hline 2017 & 11-May & & 47 & 87 & 72 & 113 & 2 & 15 & 15 & 15 & 14 & 15 & 74 & green & sweet flowery & roast \\
\hline
\end{tabular}


Table 2. Identification of Key Odorants in the Volatile Fractions Isolated from the Sencha Infusions

\begin{tabular}{|c|c|c|c|c|c|c|}
\hline \multirow{3}{*}{ Odorant } & \multirow[b]{3}{*}{ Odor Quality } & \multirow[b]{3}{*}{ Fraction $^{\mathrm{a}}$} & \multicolumn{4}{|c|}{ Identification } \\
\hline & & & \multicolumn{2}{|c|}{$\operatorname{SIM}^{b} \mathrm{~m} / \mathrm{z}$} & \multicolumn{2}{|c|}{ Retention Index ${ }^{\mathrm{C}}$} \\
\hline & & & $\begin{array}{l}\text { Product } \\
\text { Ion }\end{array}$ & $\begin{array}{l}\text { Molecular } \\
\text { Ion }\end{array}$ & PureWAX & DB-5MS \\
\hline 12 or 3 methylbutanal ${ }^{d}$ & sweet & $\mathrm{N}-2$ & & & 906 & 651 \\
\hline 2 2,3-butanedione ${ }^{d}$ & sweet & $\mathrm{N}-3$ & & & 994 & \\
\hline 31 -penten-3-one ${ }^{e}$ & floral & $\mathrm{N}-3$ & 55 & 84 & 1012 & 679 \\
\hline 4 unknown $^{f}$ & sulfy & & & & 1038 & \\
\hline 5 hexanal & green & $\mathrm{N}-2$ & & & 1091 & 803 \\
\hline 6 unknown $^{f}$ & fruity & & & & 1095 & \\
\hline 7 dimethyl disulfide ${ }^{e, g}$ & sulfy & A & 79 & 94 & 1100 & 785 \\
\hline $8(Z)-3$-hexenal ${ }^{\mathrm{e}}$ & green & $\mathrm{N}-3$ & 69 & 98 & 1134 & 800 \\
\hline 9 unknown $^{f}$ & green & $\mathrm{N}-2$ & & & 1192 & \\
\hline 10 ethy I hexanoate & fruity & $\mathrm{N}-2$ & & & 1214 & 1002 \\
\hline $11(Z)$-4-heptenal ${ }^{\mathrm{e}}$ & green & $\mathrm{N}-2$ & 68 & 112 & 1225 & 901 \\
\hline 12 octanal & fruity & $\mathrm{N}-2$ & & & 1272 & 1006 \\
\hline 131 -octen-3-one $e^{e}$ & green & $\mathrm{N}-3$ & 70 & 126 & 1291 & 978 \\
\hline 142 -acetyl-1-pyrrol ine $e^{e}$ & roasty & $B, N-5$ & 83 & 111 & 1324 & 921 \\
\hline $15(Z)-1,5$-octadien-3-one $\mathrm{e}^{\mathrm{e}}$ & metalic-like & $\mathrm{N}-3$ & 55 & 124 & 1363 & 981 \\
\hline 164 -mercapto-4-methyl-2-pentanone ${ }^{\mathrm{e}}$ & meaty & A & 99 & 132 & 1369 & 1006 \\
\hline $17(Z)$-3-hexanol & green & & & & 1365 & 858 \\
\hline 18 nonanal & fruity & $\mathrm{N}-2$ & & & 1387 & 1103 \\
\hline 19 unknown $^{f}$ & floral & & & & 1409 & \\
\hline 20 furfury 1 mercaptan ${ }^{e}$ & roasty & A & 81 & 114 & 1422 & 910 \\
\hline 212 -i sopropyl-3-methoxypyrazine ${ }^{e}$ & earthy & B & 137 & 152 & 1424 & 1097 \\
\hline 22 methional $^{\mathrm{e}, \mathrm{g}}$ & green & $A, N-5$ & & 104 & 1444 & 908 \\
\hline 23 2-ethy I-3, 5-d imethy I pyraz ine & roasty & B & & & 1449 & 1089 \\
\hline $24(E, E)$-2, 4-heptadienal ${ }^{\ominus}$ & fatty & $\mathrm{N}-3$ & 81 & 110 & 1495 & 1013 \\
\hline 25 benzaldehyde & floral & $\mathrm{N}-2$ & & & 1507 & 960 \\
\hline 262 -i sobutyl-3-methoxypyrazine ${ }^{e}$ & earthy & $B, N-5$ & 124 & 166 & 1517 & 1175 \\
\hline $27(E)$-2-nonenal & green & $\mathrm{N}-2$ & & & 1522 & 1158 \\
\hline 28 |inalool & floral & $\mathrm{N}-4$ & & & 1537 & 1101 \\
\hline $29(E, Z)-2,6$-nonadienal ${ }^{\mathrm{e}}$ & green & $\mathrm{N}-3$ & 70 & 138 & 1572 & 1150 \\
\hline 30 unknown $^{f}$ & green & & & & 1599 & \\
\hline 31 unknown $^{f}$ & green & & & & 1605 & \\
\hline 32 butanoic acid & pungent & A & & & 1609 & 821 \\
\hline 33 phenylacetaldehyde & floral & & & & 1614 & 1049 \\
\hline 34 iso valeric acid & unpleasant & A & & & 1650 & 835 \\
\hline $35(E, E)-2,4$-nonadienal ${ }^{\mathrm{e}}$ & green & $\mathrm{N}-3$ & 81 & 138 & 1680 & 1217 \\
\hline 363 -methy Inonane-2, 4-dione ${ }^{e}$ & green & $\mathrm{N}-3$ & 99 & 170 & 1706 & 1256 \\
\hline 37 -acetyl-2-thiazol ine ${ }^{e}$ & roasty & $\mathrm{N}-4$ & & 129 & 1740 & 1108 \\
\hline $38(E, E)-2,4$-decadienal ${ }^{\mathrm{e}}$ & fruity & $\mathrm{N}-3$ & 81 & 152 & 1794 & 1325 \\
\hline $39 \beta$-damascenone $e^{\text {e,g }}$ & sweet & $\mathrm{N}-3$ & 177 & 192 & 1802 & 1387 \\
\hline 40 3-mercapto-1-hexanol ${ }^{\mathrm{e}}$ & fruity & A & 55 & 134 & 1821 & 1125 \\
\hline 41 geraniol & floral & $\mathrm{N}-4$ & & & 1829 & 1250 \\
\hline 42 guaiacol & spicy & A & & & 1834 & 1086 \\
\hline $43 \gamma$-octalactone ${ }^{e}$ & sweet & $\mathrm{N}-4$ & 85 & & 1889 & 1250 \\
\hline 44 unknown $^{f}$ & green & & & & 1906 & \\
\hline $45 \beta$-ionone & green & $\mathrm{N}-4$ & & & 1930 & 1480 \\
\hline 46 maltol & sweet & $\mathrm{N}-5$ & & & 1936 & 1090 \\
\hline 47 trance-4,5-epoxy- $(E)-2$-decenal $\mathrm{I}^{\mathrm{e}}$ & sweet & $\mathrm{N}-3$ & 68 & & 1984 & 1399 \\
\hline $48 \gamma$-nonalactone ${ }^{\mathrm{e}}$ & sweet & $\mathrm{N}-4$ & 85 & & 2000 & 1365 \\
\hline 49 4-hydroxy-2, 5-dimethyl-3(2H)-furanone (furaneol) & sweet & $\mathrm{N}-4$ & & & 2005 & 1066 \\
\hline 50 unknown $^{f}$ & burnt & & & & & \\
\hline $51 p$-cresol & spicy & A & & & 2061 & 1063 \\
\hline 52 2-ethy I-4-hydroxy-5-methy I-3 (2H)-furanone & sweet & $\mathrm{N}-4$ & & & 2068 & 1160 \\
\hline 53 2-methoxyviny Iphenol & spicy & A & & & 2141 & 1306 \\
\hline 54 eugenol & spicy & A & & & 2144 & 1353 \\
\hline 55 bis (2-methyl 3-furyl) disulfide $e^{e, g}$ & meaty & A & 113 & 226 & 2154 & 1540 \\
\hline 56 sotolon $^{\mathrm{e}, \mathrm{g}}$ & spicy & A & & 128 & 2163 & 1112 \\
\hline 57 jasmine lactone & sweet & $\mathrm{N}-4$ & & & 2232 & 1494 \\
\hline 58 unknown $^{f}$ & green & & & & 2239 & \\
\hline 59 unknown $^{\dagger}$ & sweet & & & & 2250 & \\
\hline 60 unknown $^{\dagger}$ & floral & & & & 2341 & \\
\hline 61 (Z)-methyl jasmonate & floral & $\mathrm{N}-4$ & & & 2370 & 1675 \\
\hline 62 unknown $^{f}$ & sweet & & & & 2382 & \\
\hline 63 indole & unpleasant & $\mathrm{N}-2$ & & & 2415 & 1291 \\
\hline 64 coumar in & sweet & $\mathrm{N}-3$ & & & 2420 & 1438 \\
\hline 65 pheny 1 acetic acid & floral & A & & & 2531 & 1271 \\
\hline 66 vanillin & sweet & $\mathrm{N}-3$ & & & 2533 & 1419 \\
\hline
\end{tabular}

${ }^{a}$ Acidic, basic and neutral fractions were isolated from aroma extract. The neutral fraction was applied to a column (60 $\times 16 \mathrm{~mm} \mathrm{i.d.,} 12 \mathrm{~mL}$ ) containing silica gel $(5 \mathrm{~g}$, particle size $40 \mathrm{~mm}$, Agilent). Samples were eluted in one of the following solvents: pentane ( $36 \mathrm{~mL}$, fraction $\mathrm{N}-1)$, pentane/dichloromethane ( $24 \mathrm{~mL} / 12 \mathrm{~mL}$, fraction $\mathrm{N}-2)$,

pentane/dichloromethane $(12 \mathrm{~mL} / 24 \mathrm{~mL}$, fraction $\mathrm{N}-3)$, dichloromethane $(36 \mathrm{~mL}$, fraction $\mathrm{N}-4)$, and ethyl acetate (50 mL, fraction N-5). "'Selected ion mode (SIM). "Retention index was caluculated by using GC-FID. ${ }^{d}$ The odorant has been identified by using the solid phase microextraction. "Since mass spectra of an odorant could not be obtained, SIM was applied to the detection of the odorant. IUnidentifed odorant. 'The odorant was not detected when the fraction was injected on the PureWAX capillary column. However, the peak was observed when the separated fraction was injected onto the DB-5MS capillary column. 


\section{5 香気寄与成分の特定}

香気寄与成分を特定するため，AEDAに用いた全て の香気エキスを既報 ${ }^{14)}$ に従い分画した。各画分に含ま れる成分を分離カラムPureWAXとDB-5MSを用いて GC-O/FIDおよびGC-MS分析し, 匂いの性質, マスス ペクトル，保持指標から成分を特定した。なお，マスス ペクトルが得られない場合，匂いの性質および保持指標 とともに, Table 2に示した各成分のプロダクトイオン と分子イオンをSelected Ion Mode (SIM) で検出する ことで特定した。

\section{6 官能検查}

パネルは以下のように訓練し, 官能検査に従事した。 特徴のある茶 ( みる芽香, 新鮮香, 青臭, 萎调臭, 葉傷み臭, むれ臭, 火香, 変質臭, 煙臭）を用意し, その特徵を言 い当てるまで繰返し行うことによる訓練を 1 週間に 1 回 以上行った。さらに, 熟度が異なる一番茶を 5 種類用意 し, 外観形状, 外観色沢, 香気, 水色, 滋味の各項目 について熟度別に言い当てる訓練を行った。半年以上の 訓練期間を経て，実験で用いる煎茶を標準審査法で評価 した。さらに，三井農林株式会社が開発したキャラク夕 ーホイール (http://www.mitsui-norin.co.jp/ochalabo/ taste/taste20180111.html）を用いて煎茶を評価した。 標準審査法と同様に煎茶の浸出液を用意し, 強く感じら れる用語をキャラクターホイールから抽出した。

\section{7 主成分分析}

主成分分析には，マイクロソフト社のExcel VBAを 用いた。

\section{3 実験結果および考察}

\section{1 官能検查}

各項目20点満点の標準審査法により煎茶を評価した (Table 1)。結果, 外観形状について2017年に山間部の 松島園で生産された煎茶は14点であったが, それ以外の 煎茶の評価点は15点であり, 外観形状において平坦部と 山間部で大きな差はなかった。外観色沢は摘採年により 評価が異なったため，製造による影響が表れたものと思 われる。平坦部で生産された煎茶の内質はすべての項目 において14点であったが，山間部で生産された煎茶は14 点および15点の評価であった。このように，外観形状の 評価は同等であっても, 内質において山間部の煎茶は優 れる傾向が見られた。
いずれの摘採年においても全ての煎茶にみる芽香が認 められた。ただし， みる芽香は平坦部より山間部の煎茶 の方が強かった。なお, 山間部のつちや農園の煎茶はみ る芽香とともに新鮮香も認められた。キャラクターホイ ールを用いた評価では, 同じ産地でも摘採年により抽出 される用語が異なった。ただし，いずれの煎茶において もsweetとgreenが抽出された。平坦部の煎茶にはspicy, dry, burnt, vegetableが抽出された。一方, 山間部の 煎茶には平坦部と同様にspicy, dry, vegetableが抽出 されたが, flowery, fruity, roastも抽出された。この ように，キャラクターホイールを用いることで香りの違 いを表すことができる。今後，パネルの訓練方法を工夫 すれば, 細分化された用語を抽出することが可能になり， よりわかりやすく香りを表現できると考えられる。

\section{2 香気寄与成分の特定}

Table 2にGC-O分析で検出された香気寄与成分, 匂 いの性質, 成分の特定に至った画分, 保持指標および FDファクターを示した。GC-O分析により66成分が検 出され，その内54成分を特定した。香気エキスをシリ カゲルカラムクロマトグラフィーで分画してGC-MS分 析してもマススペクトルが得られない成分は, 既報 ${ }^{5)}$ と同様にプロダクトイオンと分子イオンをSIMで検出 し，保持時間の一致を確認することで推定した。ただ し, No. 7 dimethyl disulfide, No.22 methional, No.39 $\beta$-damascenone, No.55 bis (2-methyl 3-furyl) disulfideは分離カラムPureWAXで検出できなかったが, 分離カラムDB-5MSを用いることで検出できた。なお, No.1およびNo. 2 はGC-MS分析において，溶媒ピークと 重なったため, 樋口ら ${ }^{15)}$ の方法を参考に固相マイクロ 抽出法で確認した。

\section{3 高いFDファクターで検出された香気寄与 成分}

山間部，平坦部の煎茶に打いて高いFDファクター （1000以上）で検出された成分は, No.15 $(Z)$-1,5-octadien3-one, No.27 (E)-2-nonenal, No.28 linalool, No.29 $(E, Z)-2,6$-nonadienal, No.36 3-methylnonane-2,4dione, No.39 $\beta$-damascenone, No.40 3-mercapto-1hexanol, No.49 furaneol, No.56 sotolon, No.61 $(Z)$ -methyljasmonate, No.63 indole, No.66 vanillinの12成 分であった (Table 3)。この内, No.15, 29, 36, 39, 40, 63は平坦部, 山間部の煎茶に共通して高いFDファ クター（1000以上）で検出されたが，No.15，39，40， 
63は低いFDファクター100以下で検出される摘採年もあ り，一定の傾向は認められなかった。No.27と28は山間 部の煎茶において高いFDファクター1000で検出される 摘採年もあるが，低いFDファクターで検出される摘採 年もあり，一定の傾向は認められない。No.49とNo.56は
山間部の煎茶から高いFDファクターで検出される摘採 年もあるが, 低いFDファクターで検出される摘採年も あった。No.61は山間部で生産された煎茶から高いFDフ アクターで検出され, 特に山間部のつちや農園産の煎茶 から摘採年に関係なく高いFDファクター1000で検出さ

Table 3. Flavor Dilution (FD) Factors of the Aroma Extracts Isolated from the infusions of Sencha Produced in the Mountainous (Mt.) Area and Flat Land

\begin{tabular}{|c|c|c|c|c|c|c|c|c|c|}
\hline \multirow{3}{*}{ Odorant } & \multicolumn{3}{|c|}{ Kanaya (flat land) } & \multicolumn{3}{|c|}{$\begin{array}{c}\text { FD factor } \\
\text { Matsushimaen (Mt. area) }\end{array}$} & \multicolumn{3}{|c|}{ Tsuchiyanouen (Mt. area) } \\
\hline & 2015 & 2016 & 2017 & 2015 & 2016 & 2017 & 2015 & 2016 & 2017 \\
\hline & 27-Apr & 26-Apr & 7-May & 30-Apr & 1-May & 12-May & 8-May & 2-May & 11-May \\
\hline 12 or 3 methy lbutanal & 100 & 100 & 10 & 100 & 10 & 100 & 100 & 100 & 10 \\
\hline 2 2,3-butanedione & & & 10 & 10 & & 10 & 10 & & \\
\hline 31 -penten-3-one & 10 & & 10 & 10 & & 10 & 10 & 10 & \\
\hline 4 unknown & & & 10 & & & 10 & & & \\
\hline 5 hexanal & & 10 & 10 & 100 & 10 & 10 & 100 & 100 & 10 \\
\hline 6 unknown & & & & & 10 & & & 10 & 10 \\
\hline 7 dimethyl disulfide & & & 10 & 10 & & 100 & 10 & & 100 \\
\hline $8(Z)$-3-hexenal & & & 10 & & 10 & 10 & 100 & 10 & 10 \\
\hline 9 unknown & & & & 10 & 10 & & 10 & 10 & \\
\hline 10 ethyl hexanoate & & & & & 10 & & & & \\
\hline 11 (Z)-4-heptenal & & & 10 & & 10 & 10 & & & \\
\hline 12 octanal & & & 10 & & 10 & 10 & & & 10 \\
\hline 131 -octen-3-one & 100 & 100 & 100 & 100 & 100 & 100 & 100 & 100 & 100 \\
\hline 14 2-acetyl-1-pyrroline & 100 & & & 10 & 10 & 100 & 10 & 10 & 100 \\
\hline $15(Z)-1,5$-octadien-3-one & 10 & 100 & 1000 & 100 & 100 & 1000 & 100 & 100 & 1000 \\
\hline 16 4-mercapto-4-methy I-2-pentanone & 100 & & 10 & 100 & 100 & 10 & 100 & & 10 \\
\hline $17(Z)-3$-hexanol & & 10 & 10 & & & & & & 10 \\
\hline 18 nonanal & & & & 10 & 10 & 10 & & & 10 \\
\hline 19 unknown & & & 10 & & & 10 & & & \\
\hline 20 furfuryl mercaptan & & & 10 & 10 & 10 & 10 & & & 10 \\
\hline 21 2-isopropyl-3-methoxypyrazine & 100 & 10 & & 100 & 10 & & & 100 & 10 \\
\hline 22 methional & 10 & & 10 & 10 & 10 & 10 & & 10 & 10 \\
\hline 23 2-ethy I-3, 5-dimethy Ipyrazine & 10 & 10 & 10 & 10 & 100 & 10 & & 10 & 10 \\
\hline $24(E, E)-2,4$-heptadienal & 10 & 100 & 100 & 10 & 100 & 100 & 100 & 10 & 100 \\
\hline 25 benzaldehyde & & & & & 10 & & & & \\
\hline 26 2-i sobutyl-3-methoxypyrazine & 100 & 100 & 100 & 10 & 100 & 10 & 10 & 100 & 10 \\
\hline $27(E)-2$-nonenal & 100 & 100 & 100 & 100 & 1000 & 1000 & 100 & 10 & 1000 \\
\hline 28 I inalool & 100 & 100 & 100 & 100 & 1000 & 1000 & 100 & 10 & 1000 \\
\hline $29(E, Z)-2,6$-nonadienal & 1000 & 1000 & 1000 & 1000 & 1000 & 10000 & 1000 & 1000 & 10000 \\
\hline 30 unknown $^{f}$ & 10 & 100 & 10 & 10 & 100 & 100 & 10 & 10 & 100 \\
\hline 31 unknown $^{\dagger}$ & & & & & 10 & 10 & 10 & 10 & 10 \\
\hline 32 butanoic acid & & & & & & 10 & 10 & 10 & 10 \\
\hline 33 phenylacetaldehyde & & 10 & & & 10 & 10 & & & 10 \\
\hline 34 iso valeric acid & & 100 & 100 & & 10 & 100 & 10 & 100 & 10 \\
\hline $35(E, E)-2,4$-nonadienal & & 100 & 10 & 10 & 100 & 10 & 10 & 100 & 100 \\
\hline 36 3-methy Inonane-2, 4-dione & 1000 & 1000 & 10000 & 1000 & 1000 & 10000 & 1000 & 1000 & 10000 \\
\hline 37 2-acetyl-2-thiazol ine & 10 & 10 & 100 & 10 & 10 & 10 & 10 & 10 & 100 \\
\hline $38(E, E)-2,4$-decadienal & & 100 & 10 & & 10 & 10 & 10 & 100 & 100 \\
\hline $39 \beta$-damascenone & 100 & 1000 & 10 & 100 & 1000 & 100 & 10 & 100 & 100 \\
\hline 40 3-mercapto-1-hexanol & 1000 & 100 & 10 & 1000 & 1000 & 1000 & 1000 & 100 & 1000 \\
\hline 41 geraniol & & 10 & & & 10 & 10 & 10 & 10 & 10 \\
\hline 42 guaiacol & & & & 10 & & 10 & 10 & & 100 \\
\hline $43 \gamma$-octalactone & & & & & 10 & & & 10 & \\
\hline 44 unknown & 10 & & & & 10 & & & & \\
\hline $45 \beta$-ionone & & & 10 & & 10 & 10 & & & 10 \\
\hline $46 \mathrm{ma} \mid$ tol & & 100 & 100 & & 10 & 100 & 10 & 100 & 100 \\
\hline 47 trance-4, 5-epoxy- $(E)-2$-decenal & & 100 & & 10 & 10 & 10 & & 100 & \\
\hline $48 \gamma$-nonalactone & & 10 & & 10 & 10 & 100 & 10 & 10 & 100 \\
\hline $\begin{array}{l}49 \text { 4-hydroxy-2, 5-dimethy I-3 (2H)-furanone } \\
\text { (furaneol) }\end{array}$ & 10 & 10 & & 10 & 100 & 1000 & 100 & 10 & 1000 \\
\hline $\begin{array}{l}50 \text { unknown } \\
51 p \text {-cresol }\end{array}$ & 10 & $\begin{array}{r}10 \\
100\end{array}$ & 10 & 10 & 10 & 100 & 10 & 10 & 10 \\
\hline $\begin{array}{l}51 p \text {-cresol } \\
52 \text { 2-ethy I-4-hydroxy-5-methy I-3 (2H)-furanone }\end{array}$ & & 100 & $\begin{array}{r}10 \\
100\end{array}$ & & & 10 & & & 100 \\
\hline 53 2-methoxyviny Iphenol & & & 10 & & 100 & 10 & & & 10 \\
\hline 54 eugenol & & 10 & 10 & 10 & 10 & 10 & & 100 & 10 \\
\hline 55 bis (2-methyl 3-furyl) disulfide & 100 & 100 & 100 & 100 & 100 & 100 & 100 & & 100 \\
\hline 56 sotolon & 10 & 100 & 10 & 10 & 100 & 1000 & 10 & 100 & 100 \\
\hline 57 jasmine lactone & & & & & & & 10 & & \\
\hline 58 unknown & & & & & & & 10 & & \\
\hline 59 unknown & & 100 & 10 & & 100 & 10 & 10 & 10 & 10 \\
\hline 60 unknown & & & 10 & & & 10 & & & 10 \\
\hline 61 (Z)-methyl jasmonate & 100 & 100 & 10 & 100 & 1000 & 100 & 1000 & 1000 & 1000 \\
\hline 62 unknown & & & & & & 10 & & & 10 \\
\hline 63 indole & 1000 & 100 & 10 & 1000 & 1000 & 100 & 1000 & 100 & 100 \\
\hline 64 coumarin & 10 & 10 & 10 & 10 & 100 & 10 & 10 & 100 & 10 \\
\hline 65 phenyl acetic acid & & & 10 & & & 10 & & & \\
\hline 66 vanillin & 10 & 100 & 10 & 10 & 1000 & 100 & 100 & 1000 & 100 \\
\hline
\end{tabular}


れた。このように多くの香気寄与成分が高いFDファク ターで検出されたが，摘採年によってFDファクターが 大きく異なる成分もあり, Table 3から山間部の煎茶の 香りの特徵を把握することは困難であると思われた。摘 採年により FDファクターが異なることは， 3.1 項で述 ベたキャラクターホイールによる評価の違いを支持する 結果と考えられる。今後，官能評価と香気寄与成分の関 連についてより詳細に明らかにしていく予定である。

\section{4 山間部の煎茶の特徵香に関与する香気寄与 成分の検索}

山間部と平坦部の煎茶の香りの違いを明確にするた め, 検出された各香気寄与成分のFDファクターの指数 を説明変数として，主成分分析を試みた。FDファク夕 一の指数を用いた理由は, ウェーバーフェヒナーの法則 に従い, 人間の感覚強度が物質量の対数に比例すること より, FDファクターの指数を用いた方が人間の感覚に 合致する值であるためである。Table 3に示した各香気 寄与成分について，3 年間のFDファクターの指数の平 均を算出し，これを説明変数として主成分分析を行った。 なお，得られた結果すべてを主成分分析したが，摘採年 によりFDファクターが異なる成分が多かったため，山 間部と平坦部で明確な違いが認められなかった。従って, 3 年間のFDファクターの指数の平均を算出し解析した。 その結果，主成分スコアの散布図（Fig. 1a）より山間部 の煎茶は平坦部の煎茶より離れた位置にプロットされ, 平坦部の煎茶とは異なる特異的な香気組成を有している ことが考えられた。さらに，因子負荷量の散布図（Fig 1b）より，その特異性に強く影響する因子を検索し た結果, No.49 furaneol, No.61 ( $Z$ )-methyl jasmonate, No.63 indole, No.66 vanillinが見出された。

これまで, furaneol, indole, $(Z)$-methyl jasmonate は山間部以外の煎茶においても高いFDファクターで検 出されている ${ }^{3)}$ 。しかし，主成分分析によって山間部の 煎茶の特徴香気寄与成分として見出された。このこと から，山間部の煎茶の香りは成分組成の影響を強く受 けることが考えられる。主成分分析によって山間部の特 徵香気寄与成分として見出されたvanillinは過去煎茶か ら高いFDファクターで検出されたことはなく, 今回山 間部の煎茶において高いFDファクター1000で検出され る摘採年があった。この成分はligninの構成要素である ferulic acidから分解と酸化により生成することが知られ ており ${ }^{16)}$ ，チャの生葉の保管により増加することが認め られている ${ }^{17)}$ ここのことから何らかの物理的ストレスに よりvanillinが生成することが示唆されるが，山間部の 環境によるものか, あるいは摘採後の挙動によるものか 検証する必要があろう。

主成分分析により山間部の煎茶の特徵成分として見出 したfuraneolは良質茶の持つ自然な甘さを ${ }^{18)}$ ，vanillinは 穏やかな甘さを付与し ${ }^{3)}$, indoleは煎茶全体の香りを強

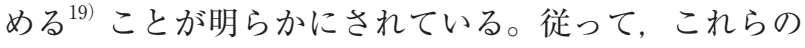
成分は山間部の煎茶の香りの特徴に有利に働いているこ とが考えられる。 $(Z)$-methyl jasmonateは爽快な花香 のある香気寄与成分であるが添加試験によりその香調を 調べた報告はない。そこで，新鮮香が認められた山間部 のつちや農園の煎茶 $3 \mathrm{~g} に(Z)$-methyl jasmonateを0.3
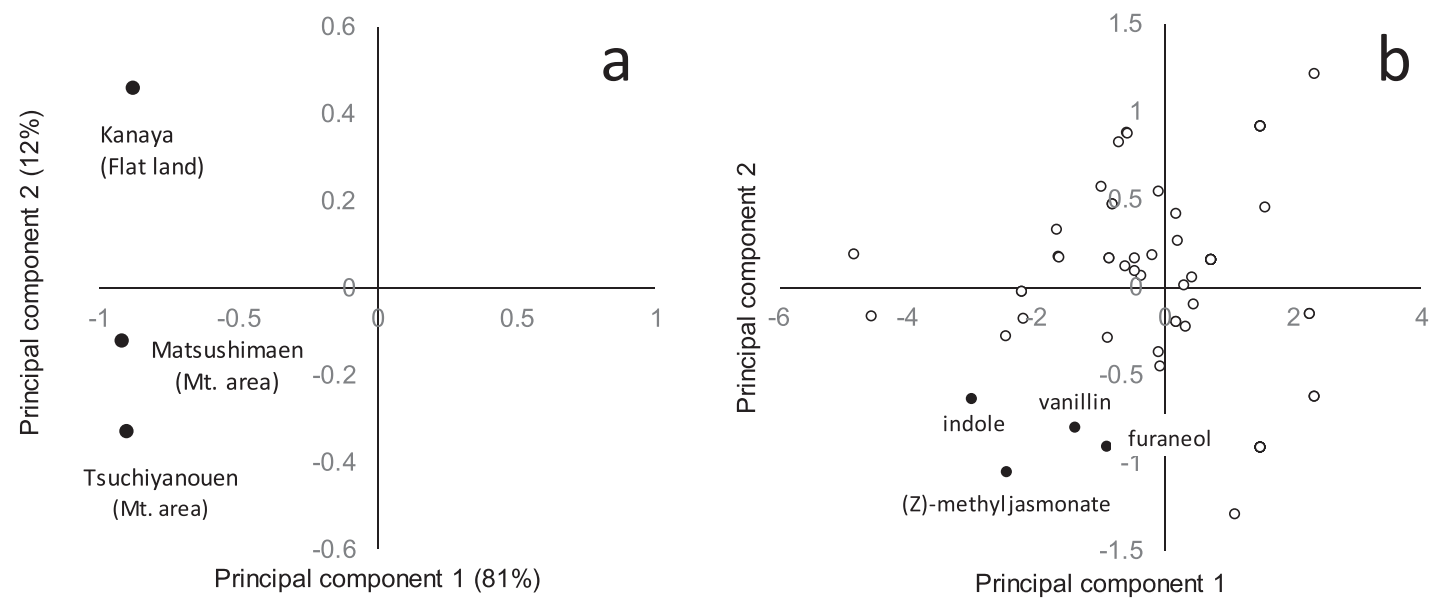

Fig. 1. Scatter plots of principal component scores (a) and factor loadings (b) obtained by the principal component analysis applied to the flavor dilution factors of all the detected odorants in the aroma extract dilution analysis of the infusions of Sencha Produced in the mountainous (Mt.) area and flat land. 
$\mu \mathrm{g}$ 加え熱湯 $200 \mathrm{~mL}$ 注いで標準審査法により香気を官能 検査したところ，新鮮香を増強することがわかった。さ らに添加する $(Z)$-methyl jasmonateを3.0 $\mu$ gに増やし たところ, 煎茶の萎调香に近い爽快な花香が感じられ た。(Z)-methyl jasmonateはlinoleic acidが前駆体とし て知られ, 分解と酸化をともない生成し ${ }^{20)}$, 萎调により 増加することが知られている ${ }^{17)}$ 。このことから, 前述し たvanillinと同様に何らかの物理的ストレスにより生成 することが示唆されるが，具体的な要因についてさらな る検証が必要であろう。

今回の結果は限られた煎茶から得られたものであり, 山間部で生産された煎茶の代表的なものを試験に用いた とは言い難い。しかし，山間部の煎茶の特徵がよく表れ たものを材料に用いたため，GC-Oを用いたAEDAと主 成分分析によりその特徽を明らかにすることができたと 考えられる。煎茶の香りは産地, 栽培および製造方法に よって異なる。さらに今回の結果から, 同じ産地でも摘 採年によりFDファクターが異なる成分もあり，摘採年 により香りが異なることがわかった。山間部の煎茶の特 徵をより明確にするためには，今後多くの煎茶を用いた 検証が必要であろう。

\section{4 謝 辞}

本研究は川根本町茶業振興協議会と農研機構果樹茶業 研究部門の両者間で締結された協定研究の一環として行 われた。ご協力頂いた川根本町役場農業振興室高畑良成 氏, 松島園川崎好和氏, つちや農園土屋和明氏並びに土 屋裕子氏に深く感謝申し上げます。

\section{5 摘 要}

山間部の煎茶の香りの特徵を明らかにするため, 山間 部で生産された煎茶の香りと平坦部で生産された煎茶の 香りを解析した。キャラクターホイールを用いた官能評 価では同じ産地でも摘採年により抽出される用語は異な った。さらに，同じ産地でも摘採年によってFDファク ターが大きく異なる成分もあり，FDファクターから山 間部の煎茶の香りの特徵を把握することは困難であると 思われた。そこで, 香気エキス希釈分析によって得られ た結果を主成分分析したところ，山間部の煎茶の特徵 香に関与する香気寄与成分としてfuraneol, (Z)-methyl jasmonate, indole, vanillinが見出された。しかし, こ れらの成分は平坦部で生産された煎茶にも含まれてい
る。従って, 山間部の煎茶の香りは香気成分の組成に影 響を受けることがわかった。

\section{6 引用文献}

1 ）和田光正 - 中田典男 - 太田勇夫 - 本荘吉夫 (1981)：産地によ る煎茶の品質および化学成分の相違. 茶研報. No.53, 26-41.

2 ) 伊藤正智 - 奥村茂夫 (1982)：山間地域の平坦部と山間部にお ける茶芽の特性. 茶研報. No. 55, 11-20.

3 ) 水上裕造 (2015) : 緑茶の香りの特徵, におい・か扔り環境学 会誌, 46, 110-120.

4 ) Kumazawa, K (2006) : Flavor chemistry of tea and coffee drinks. Food. Sci. Technol. Res., 12, 71-84.

5 ) 水上裕造 (2017)：Solvent-assisted flavor evaporation装置を 用いた高真空蒸留と香気エキス希釈分析法による台湾産半発 酵茶の香気寄与成分の特定. 茶研報. No.123, 9-16.

6 ) 水上裕造 - 山口優一 (2010) : Solvent-assisted flavor evaporation 装置を用いた茶に含まれる香気成分の分析法. 茶研報, No.110, 105-112.

7 ) Kimpe, N. G. D., C. V. Stevens and M. A. Keppens (1993) : Synthesis of 2-acetyl-1-pyrroline, the principal rice flavor component. J. Agric. Food Chem., 41, 1458-1461.

8 ) Swoboda, P. A. T. and Peers, K. E. (1977) : Metallic odour caused by vinyl ketones formed in the oxidation of butterfat. The identification of octa-1-cis-5-dien-3-one. J. Sci. Food Agric., 28, 1019-1024.

9 ) Guth, H. (1997) : Identification of character impact odorants of different white wine varieties. J. Agric. Food Chem., 45, 3022-3026.

10) Yuasa, Y. and Y. Kato (2001) : Practical synthesis of 3-methylnonane-2,4-dione, an intense strawlike and fruity flavored compound. J. Agric. Food Chem., 49, 3864-3866.

11) Ong, P. K., T. E., Acree and E. H. Lavin (1998) : Characterization of volatiles in Rambutan Fruit (Nephelium Lappaceum L.). J. Agric. Food Chem., 46, 611-615

12) Mukaiyama, T., J. Matsuo and M. Yanagisawa (2001) : A mild and efficient oxidation of alcohols with N-tertbutylphenylsulfinimidoyl chloride in the coexistence of zinc oxide. Chem. Lett., 30, 150-151.

13）水上裕造 (2012)：Solvent-assisted flavor evaporation装置を 用いた高真空蒸留と香気エキス希釈分析法によるほうじ茶葉 香気寄与成分の特定. 茶研報, No.113, 55-62.

14）水上裕造 - 崎原敏博 - 遠矢聡志 - 内村浩二 (2014) : 夏茶に含 まれる香気寄与成分. 茶研報, No.117, 27-33.

15）樋口雅彦 - 佐藤昭一 - 浜崎正樹 - 眞正清司 - 堀田 博 (2004)： 固相マイクロ抽出 (SPME) 法による茶の加熱香気成分の分 析法. 茶研報, No.98, 33-42.

16）小関卓也・岩野君夫（1998）：泡盛中のバニリンの意義と生成 機構. 日本醸造協会, 93, 510-517.

17）水上裕造 - 崎原敏博 - 飛松 諒 - 内村浩二（2015）：生葉の低 温保管による夏茶臭改善効果の解明. 茶研報, No.119, 21-28.

18）小川香料株式会社, 茶飲料用添加剂, 特開2007-167003.

19）水上裕造・山口優一 (2009) : 香気エキス希釈分析法を用いた 緑茶の萎调香に関与する成分の同定. 茶研報, No.107, 81-84.

20) Yang, Z., S. Baldermann and N. Watanabe (2013) : Recent studies of the volatile compounds in tea. Food Res. Int., 53, 585-599. 